\title{
ENVIRONMENTAL IMPACT OF BITUMEN ON SOIL, WATER AND PLANT IN LODASA AREA, ODE-IRELE, ONDO STATE, NIGERIA
}

\author{
K. Ogedengbe ${ }^{1}$ and C.O. Akinbile ${ }^{2}$ \\ ${ }^{1}$ Department of Agricultural and Environmental Engineering, Faculty of Technology, \\ University of Ibadan, Nigeria \\ ${ }^{2}$ Department of Agricultural Engineering, Federal University of Technology, Akure, Nigeria
}

\begin{abstract}
Six sites containing various plants with different indicator parts were analyzed for the environmental effects of bitumen on the plants and animals. From the location, which is in Lodasa, Ode-Irele Local Government Area of Ondo State, twelve soil samples, six plant and water samples were collected to study the effects of bitumen on them. Results show that the percentage composition of nitrogen in the plants ranged from 0.069-0.078, for phosphorous it ranged from 0.031-0.068, potassium from 0.160.23 , calcium ranged from 0.212-0.288, for magnesium, 0.104-0.188. Constituents of Manganese ranges from 17.07-21.03 ppm, Zinc 13.25-16.20 ppm, Copper, 1.93-2.33 ppm and Iron ranges from 31.25-36.24 ppm all in plants analyzed. As for the composition of these constituents in soils, Nitrogen ranges from 1.058-3.61 ppm, Calcium, 0.66-0.88 ppm, Magnesium, 0.65-0.88 and organic matter ranges from 1.788-2.142 ppm. Evidently these show that the soils cannot support plant growth and their effects were manifested in visual signs of dying plants in the bitumen affected areas. The results for water samples have values below the standard recommended by the World Health organization (WHO) for safe drinking water while calcium and manganese values are above the WHO Standard. As for the results of waters samples analyzed, Manganese ranges from 1.63-2.94 ppm, Calcium, 3.22- 8.63 ppm, Iron 0.28-0.43ppm, Copper 0.19-0.38ppm while Magnesium ranges from 2.854.77 ppm. These show that the water was toxic and injurious to human, animals and aquatic lives. Statistical analysis shows a positive linear correlation between the presence of nutrients in plants and the soil, which is responsible for the retarded growth and yellow colouration of the leaves. The presence of bitumen in Lodasa soil is fast eroding soil fertility in the area and has contributed immensely to low yield of Agricultural products. The use of organic fertilizer to boost soil fertility, relocation and resettlement of farmers to areas with high soil fertility and appropriate legislation to protect the rights of the native settlers are some of the recommendations.
\end{abstract}

Keywords: Bitumen, Elements, soil, plant, water, Lodasa 


\section{INTRODUCTION}

Bitumen is defined as a sticky substance obtained from crude oil and use for covering roads or roofs (Ekweozor and Unomah, 1989). It originated from fossil deposit, which represents the product of reservoir transformation of convectional oil by microorganism. The experience of tars and petroleum exploitation has created oil pollution and spillages on the communities, affecting land, crop, water and welfare of host communities (Ozumba, 1996). Local communities have raised their concern over health and quality of life the pollution has on their water and aquatic life, land are crops. In Nigeria, the residents of mineral resources exploitation areas are traditionally farmers. Due to the introduction of toxic chemicals into the sea by of companies in their quest for oil, massive migration of various fish species from coastal areas had taken place so also is the constant menace of gasses which are creating health problems. Added to these are numerous incidents of oil spillage, which scorched the soil and makes farming unprofitable (Eghagha, 2001). The overall effect of environmental degradation on the people especially the poor can be summarized in the word of Mink (1991) who stated that "environmental degradation decreases the production of those natural resources from which the poor wrest their livelihoods." There is therefore the need to address the problem especially as it affects agricultural productivity in such areas. No mineral resource is environmentally friendly when it comes to its exploitation. Whenever there is any exploitation, there must be an impact on the communities and in most cases, negatively. Several studies of the environmental impact of gas flaring on Izombe flow station in Imo State and carried out by Okeke and Okezie (1987) revealed staggering evidence of environmental damage resulting in low agricultural productivity of the affected area.

Mimiko (2000) argued that in as much as mineral resources exploitation would enhance the revenue outlay of Nigeria; the ecological consequences of it are grave, because these may not be manifested in the immediate more so that the Nigerian state has consistently refused to make the people the central part of crude oil economy. The need to arrest the environmental effects of bitumen in Lodasa becomes imperative due to the fact that the farmland can no longer support agricultural practices as a result of the chemical components of bitumen and its negative effect on, soil, water and plant growth.

The objective of this study therefore, is to investigate the environmental effect of bitumen deposits on soil, water and crop in Lodasa area of Ondo state. Also, to study the extent and degree of pollution of the 'black gold' within the study area as it affects its inhabitants.

\section{MATERIALS AND METHODS \\ Study area}

Lodasa area is part of the bitumen deposit zone within Ondo state, South Western Nigeria. It is located between latitudes $4^{0} 45^{1} \mathrm{E}$ to $5^{0} 0^{1} \mathrm{E}$ and longitudes $6^{0} 15^{1} \mathrm{~N}$ to $6^{0} 47^{1} \mathrm{~N}$ with a climate of tropical wet and dry with well defined rain and dry seasons. The predominant occupation of the inhabitants is farming (crop and livestock). Agricultural technology has remained relatively unchanged over the years and over $90 \%$ of the farmers practiced subsistent farming using simple tools. The discovery and subsequent exploration of bitumen ordinarily should have brought about development in the area but the adverse environmental impact of it had brought untold hardship on the human, plant, animals, water and soil of Lodasa area of Ondo State, Nigeria

Twelve soil samples were taken at depth of 0 $30 \mathrm{~cm}$ (using auger) within Lodasa area of OdeIrele. The samples were taken within the distance of between 5 and $10 \mathrm{~m}$. Six plant samples, taken at a distance of $3 \mathrm{~m}$ from six different locations within a farm in Lodasa were also analyzed. The plant indicator parts taken for analysis were, Cocoa, plantain, cassava, yam, maize and kola nut leaves. Six water samples taken at a distance of $3 \mathrm{~m}$ in six different locations along river Opa were taken to the International Institute of Tropical

2 Journal of Science and Technology, Vol. 29, No. 1, April, 2009 
Agriculture (IITA) laboratory for analysis in line with AOAC (1990) procedures. The samples analysis covered mineral compositions such as Nitrogen, Phosphorus, Potassium, Calcium, Manganese, Magnesium, Zinc, Copper and Iron. Statistical analyses was carried out using correlation coefficients, coefficient of determination and other related packages to determine variation and level of significance at $\mathrm{P}>0.05$.

\section{RESULTS AND DISCUSSION}

The analyses of both plant and soil samples at different locations in Lodasa area strongly indicate adverse impact of bitumen exploration on the farm. Adopting J.B Robinson's standards (as used by Ozumba, 1996) for nutrient concentration in the plant and soil, the results are as shown in Tables 1 and 2 .

Table 1: Nutrient Concentration in Plants

\begin{tabular}{llllll}
\hline Nutrient & Deficient & Marginal & Critical & Adequate & High/Toxic \\
\hline $\mathrm{N}(\%)$ & - & - & - & $3.5-5.0$ & - \\
$\mathrm{P}(\%)$ & 0.15 & - & 0.25 & $0.25-0.4$ & 0.5 \\
$\mathrm{~K}(\%)$ & 1.25 & - & - & $1.71-2.25$ & 2.5 \\
$\mathrm{~S}(\%)$ & - & - & 0.24 & $0.2-0.3$ & - \\
$\mathrm{Ca}(\%)$ & 0.1 & - & 0.4 & $0.4-0.5$ & - \\
$\mathrm{Mg}(\%)$ & 0.12 & - & 0.3 & $0.3-0.46$ & - \\
$\mathrm{Mn}(\mathrm{ppm})$ & 10 & - & 25 & $100-2200$ & $4000-6000$ \\
$\mathrm{Zn}(\mathrm{ppm})$ & 14 & $14-20$ & 18 & $21-35$ & $>35$ \\
$\mathrm{Fe}(\mathrm{ppm})$ & - & - & 80 & $80-200$ & - \\
$\mathrm{Cu}(\mathrm{ppm})$ & - & $3-7$ & 9 & $9-20$ & - \\
\hline
\end{tabular}

Source: Ozumba (1996)

Table 2: Nutrients Concentrations in Soil

\begin{tabular}{llllll}
\hline Nutrient & Deficient & Marginal & Critical & Adequate & High/Toxic \\
\hline $\mathrm{N}(\%)$ & 2.6 & $2.6-2.8$ & - & $2.8-4.0$ & - \\
$\mathrm{P}(\%)$ & 0.13 & $0.13-0.19$ & $0-2$ & $0.2-0.25$ & - \\
$\mathrm{C}(\%)$ & 0.5 & $0.5-1.5$ & $1.5-3.0$ & - & $>3.5$ \\
$\mathrm{Ca}(\%)$ & 0.5 & $0.5-0.7$ & - & $0.8-1.2$ & 1.25 \\
$\mathrm{Mg}(\%)$ & 0.2 & $0.2-0.3$ & - & $0.3-0.46$ & - \\
$\mathrm{K}(\%)$ & 0.5 & $2.5-3.0$ & - & $3.1-4.0$ & - \\
$\mathrm{Na}(\%)$ & - & - & 0.005 & $0.01-0.10$ & - \\
$\mathrm{Mn}(\mathrm{ppm})$ & 10 & $10-20$ & 25 & $100-220$ & - \\
$\mathrm{Fe}(\mathrm{ppm})$ & - & - & 80 & $70-200$ & - \\
$\mathrm{B}(\mathrm{ppm})$ & 10 & $10-20$ & 11 & $20-80$ & $80-300$ \\
$\mathrm{Cu}(\mathrm{ppm})$ & - & $3-7$ & 9 & $9-20$ & - \\
\hline $\mathrm{Zn}$ & 14 & $14-20$ & - & $21-35$ & $>35$ \\
$\mathrm{Source:}$ Ozumba $(1996)$ & & & & \\
\hline
\end{tabular}


From Table 3, only Iron was found to be at adequate levels in soil among the micro nutrients in all the six sampling points. Major element such as Potassium and Carbon were found at deficient and marginal levels respectively. Nitrogen (N) and calcium $(\mathrm{Ca})$ were found to be adequate while zinc $(\mathrm{Zn})$ and copper $(\mathrm{Cu})$ were found to be at right levels (Table 3 ). The indication of all these are that the soils in these areas cannot support plant growth. These effects were also manifested in the visual signs of dying Cocoa plants in bitumen deposit areas. The $\mathrm{pH}$ of the soil ranged from 3.78 - 4.41 (Table 3) i.e. acidic in nature. This shows that the soil cannot support plant growth rather; retardation in growth and development of plants as a result of acidic nature of the soil were experienced. This agreed with Fayemi (1975) that plants growing in oil polluted soil will suffer retardation and chlorisis of leaves as well as dehydration of plants indicating water deficiency.

The results of plant analysis (as shown in Table 4) show that major elements $(\mathrm{N}, \mathrm{P}, \mathrm{K}, \mathrm{Mg})$ were found at deficient levels in all the six locations while $\mathrm{Ca}$ was at toxic level. Also from the table micro elements ( $\mathrm{Mn}, \mathrm{Fe}, \mathrm{Zn}$, and $\mathrm{Cu}$ ) were found at deficient and marginal levels. This indicate that due to the continuous contact of the chemical contents of the bitumen with soil and plant roots, nutrients and water absorption from the soil for plant development becomes difficult. It was inferred that the plant nutrients status in both the plants and soil tend to have similar pattern in all the six locations investigated.

\section{Results of Statistical Analysis}

The results of the correlation analysis of the nine elements determined and their co- variability index relating their presence in plant and soil as shown in Table 5. For nitrogen, there is a positive linear correlation in its contents in plant and soil. The Pearson correlation coefficient was 0.02 while its coefficient of determination (R) is $0.06 \%$. This indicates that there is deficiency in the quantity of nitrogen in the soil. Also, the indi-

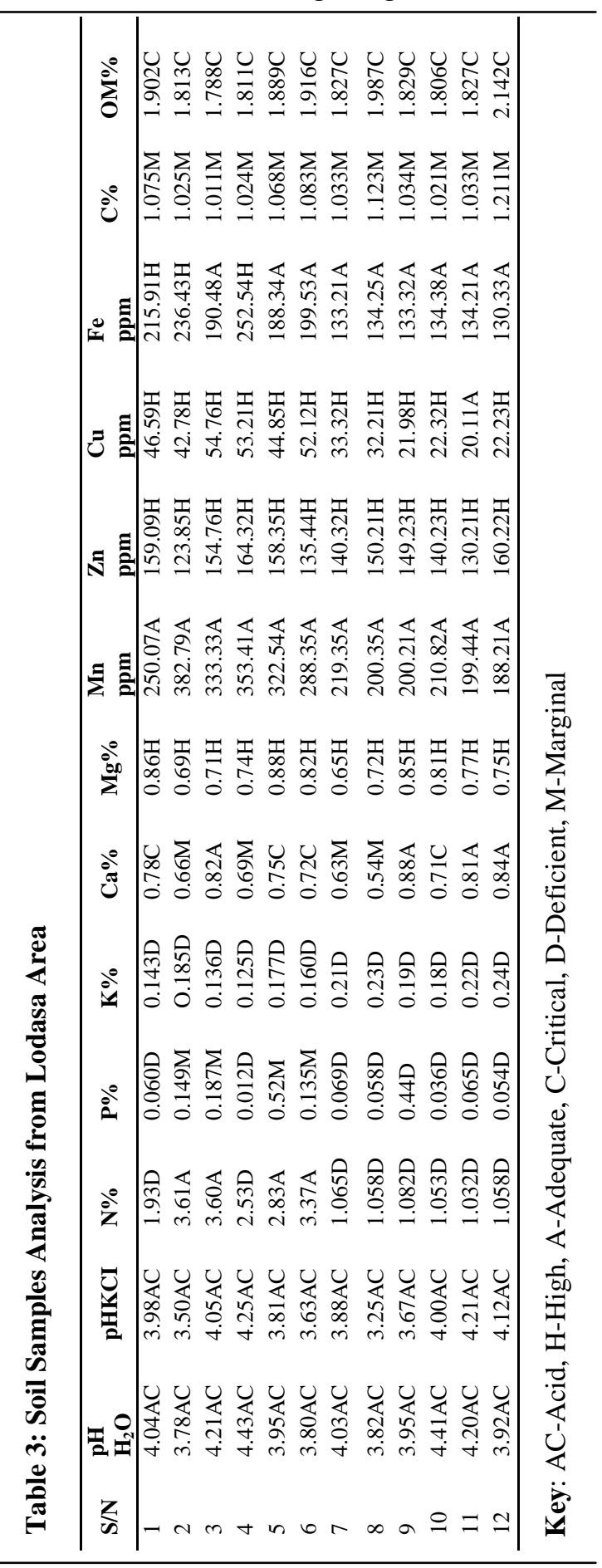

4 Journal of Science and Technology, Vol. 29, No. 1, April, 2009 
Environmental impact of bitumen on soil, water ...

Ogedengbe and Akinbile

Table 4: Plant Samples Analysis from Lodasa Area Ode-Irele

\begin{tabular}{llllllllll}
\hline $\mathbf{S} / \mathbf{N}$ & $\mathbf{N} \%$ & $\mathbf{P} \%$ & $\mathbf{K} \%$ & $\mathbf{C a} \%$ & $\begin{array}{l}\mathbf{M g} \\
(\mathbf{p p m})\end{array}$ & $\begin{array}{l}\mathbf{M n} \\
(\mathbf{p p m})\end{array}$ & $\begin{array}{l}\mathbf{Z n} \\
(\mathbf{p p m})\end{array}$ & $\mathbf{C u}(\mathbf{p p m})$ & $\begin{array}{l}\mathbf{F e} \\
(\mathbf{p p m})\end{array}$ \\
\hline 1 & $0.075 \mathrm{D}$ & $0.068 \mathrm{D}$ & $0.20 \mathrm{D}$ & $0.232 \mathrm{C}$ & $0.132 \mathrm{D}$ & $21.01 \mathrm{M}$ & $16.14 \mathrm{M}$ & $2.34 \mathrm{D}$ & $36.24 \mathrm{M}$ \\
2 & $0.078 \mathrm{D}$ & $0.031 \mathrm{D}$ & $0.16 \mathrm{D}$ & $0.212 \mathrm{C}$ & $0.104 \mathrm{D}$ & $17.07 \mathrm{M}$ & $12.23 \mathrm{D}$ & $1.93 \mathrm{D}$ & $30.17 \mathrm{M}$ \\
3 & $0.073 \mathrm{D}$ & $0.045 \mathrm{D}$ & $0.18 \mathrm{D}$ & $0.295 \mathrm{C}$ & $0.162 \mathrm{D}$ & $18.21 \mathrm{M}$ & $14.32 \mathrm{M}$ & $1.97 \mathrm{D}$ & $35.33 \mathrm{M}$ \\
4 & $0.077 \mathrm{D}$ & $0.052 \mathrm{D}$ & $0.18 \mathrm{D}$ & $0.234 \mathrm{C}$ & $0.123 \mathrm{D}$ & $20.25 \mathrm{M}$ & $14.67 \mathrm{M}$ & $2.030 \mathrm{D}$ & $37.20 \mathrm{M}$ \\
5 & $0.069 \mathrm{D}$ & $0.039 \mathrm{D}$ & $0.21 \mathrm{D}$ & $0.288 \mathrm{C}$ & $0.115 \mathrm{D}$ & $21.03 \mathrm{M}$ & $13.03 \mathrm{D}$ & $2.15 \mathrm{D}$ & $31.25 \mathrm{M}$ \\
6 & $0.074 \mathrm{D}$ & $0.054 \mathrm{D}$ & $0.23 \mathrm{D}$ & $0.255 \mathrm{C}$ & $0.188 \mathrm{C}$ & $20.58 \mathrm{M}$ & $16.20 \mathrm{M}$ & $2.33 \mathrm{D}$ & $32.33 \mathrm{M}$ \\
\hline
\end{tabular}

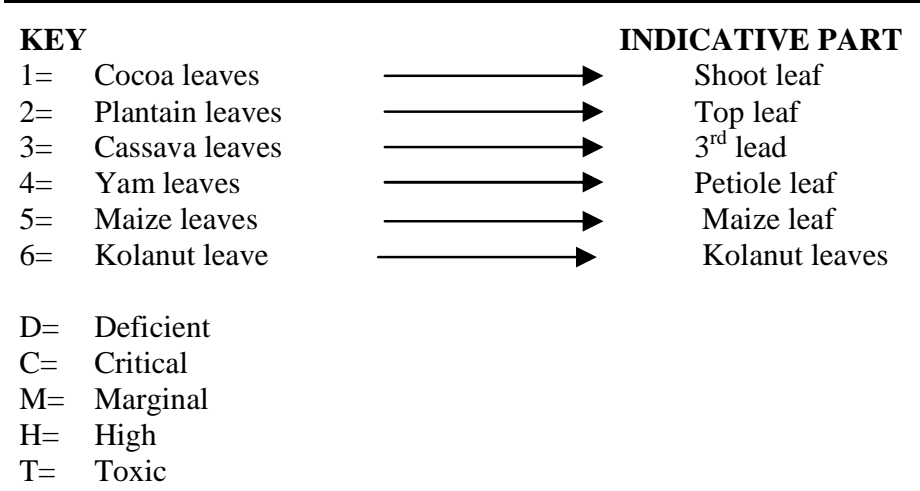

Table 5: Pearson's Correlation Coefficients $/$ Prob $>/ R /$ Under H.O Rho=P/M=6

\begin{tabular}{lccc}
\hline Elements & $\begin{array}{c}\text { Correlation coefficient } \\
(\mathbf{r})\end{array}$ & $\begin{array}{c}\text { Coefficients of determi- } \\
\text { nation (r) } \%\end{array}$ & $\begin{array}{c}\text { Probability correlation } \\
\text { for both soil and plant }\end{array}$ \\
\hline $\mathrm{N}$ & 0.02 & 0.06 & 0.97 \\
$\mathrm{P}$ & -0.59 & 3.51 & 0.22 \\
$\mathrm{Ca}$ & -0.56 & 31 & 0.22 \\
$\mathrm{~K}$ & 0.04 & 0.17 & 0.94 \\
$\mathrm{Mg}$ & 0.09 & 0.93 & 0.86 \\
$\mathrm{Mn}$ & -0.72 & 52.5 & 0.11 \\
$\mathrm{Fe}$ & 0.16 & 2.78 & 0.75 \\
$\mathrm{Zn}$ & 0.32 & 10.5 & 0.53 \\
$\mathrm{Cu}$ & 0.30 & 9.22 & 0.56 \\
\hline
\end{tabular}


cation that the plant roots find it difficult to obtain nutrients from bitumen dominated soil was evident. This led to retarded growth, thin stem and sprouting of yellow leaves at the lower parts. The same could be said of calcium with correlation coefficient of 0.56 and coefficient of determination $(\mathrm{R})$ is $31 \%$. Low calcium content in the soil is inadequate for plant use. Similar comments can be made for elements such as phosphorous, potassium, zinc, copper magnesium, manganese and Iron. Positive linear relationship in correlation coefficients and high correlation determination are indications of their low presence in soil which makes it even harder for plants to survive on them.

\section{Effect of Bitumen on Water Base Chemical Parameters}

Six water samples taken from six different locations along river Opa were analyzed to determine the effects of bitumen on its chemical parameters. The parameters determined are $\mathrm{pH}, \mathrm{PO}_{4}, \mathrm{NO}_{3}, \mathrm{Ca}$, $\mathrm{Mg}, \mathrm{Na}, \mathrm{Mn}, \mathrm{Fe}, \mathrm{Zn}$ and $\mathrm{Cu}$ the results are as presented in Table 6.

For $\mathrm{pH}$, the values ranged from 4.9-5.5, 0.08$0.23 \mathrm{ppm}$ for $\mathrm{NO}_{3}, 0.08-0,21 \mathrm{ppm}$ for $\mathrm{NH}_{4}$. Others are $3.22-8-6.3 \mathrm{ppm}(\mathrm{Ca}), 2.85-4.77 \mathrm{ppm}(\mathrm{Mg})$, 2.15-3.20ppm (Na) and 1.63-2.94ppm (Mn). The rest are $\mathrm{Zn}(0.15-0.29 \mathrm{ppm}), \mathrm{Fe}(0.28-0.43 \mathrm{ppm})$ and $\mathrm{Cu}(0.19-0.38 \mathrm{ppm})$. All these were compared with the WHO Standard minimum permissible level for drinking water. On the account of this,
$\mathrm{Mg}, \mathrm{Fe}, \mathrm{Zn}, \mathrm{Cu}, \mathrm{Na}$ and $\mathrm{NO}_{3}$ concentration in all the water samples fall below the WHO standard while $\mathrm{Ca}$ and $\mathrm{Mn}$ were above the WHO standard.

As a result of the concentration of these constituents in the stream, water in this area is not palatable for human and domestic uses. This may be responsible for death of aquatic animals in the river. High content of $\mathrm{Ca}$ in water leads to excessive scale formation, high $\mathrm{Fe}$ content makes the water objectionable to sight high contents of $\mathrm{Na}$ and $\mathrm{Mn}$ leads to bitter taste, discoloration and turbidity. The cumulative effect of these high concentrations is injurious to health of the consumers (Akinbile 2004)

On the whole, the effect of bitumen deposits on soil, plant and water in Lodasa community of Ode -Irele local Government area of Ondo State is degrading not only to the environment but also to the inhabitants. It does not allow the soil to support plant growth and therefore does not sustain healthy living of the dwellers and the environment of Lodasa community.

\section{CONCLUSIONS AND RECOMMENDATIONS}

An attempt has been made to assess the environmental impact of bitumen on soil, water and plant in Lodasa, area of Ode Irele in Ondo State, Nigeria

Based on our findings it was confirmed that bitumen affected farm land cannot support plant growth, but rather caused harmful impact to the

Table 6: Water Samples from Lodasa Area, Ode-Irele, Ondo State

\begin{tabular}{cllllllllll}
\hline $\begin{array}{l}\text { Water } \\
\text { samples }\end{array}$ & $\begin{array}{l}\mathbf{p H} \\
(\mathbf{H} \mathbf{0})\end{array}$ & $\begin{array}{l}\mathbf{N O}_{\mathbf{3}} \\
(\mathbf{p p m})\end{array}$ & $\begin{array}{l}\mathbf{N H}_{\mathbf{4}} \\
(\mathbf{p p m})\end{array}$ & $\begin{array}{l}\mathbf{C a} \\
(\mathbf{p p m})\end{array}$ & $\begin{array}{l}\mathbf{M g} \\
(\mathbf{p p m})\end{array}$ & $\begin{array}{l}\mathbf{N a} \\
(\mathbf{p p m})\end{array}$ & $\begin{array}{l}\mathbf{M n} \\
(\mathbf{p p m})\end{array}$ & $\begin{array}{l}\mathbf{F e} \\
(\mathbf{p p m})\end{array}$ & $\begin{array}{l}\mathbf{Z n} \\
(\mathbf{p p m})\end{array}$ & $\begin{array}{l}\mathbf{C u} \\
(\mathbf{p p m})\end{array}$ \\
\hline 1 & 5.50 & 0.15 & 0.09 & 3.41 & 2.85 & 2.15 & 1.63 & 0.28 & 0.15 & 0.19 \\
2 & 5.30 & 0.23 & 0.13 & 8.63 & 4,77 & 3.20 & 2.94 & 0.43 & 0.29 & 0.36 \\
3 & 5.20 & 0.21 & 0.21 & 3.22 & 3.20 & 2.84 & 1.85 & 0.23 & 0.17 & 0.23 \\
4 & 5.00 & 0,19 & 0.08 & 5.32 & 3.11 & 2.33 & 2.43 & 0.32 & 0.19 & 0.25 \\
5 & 4.90 & 0.08 & 0.11 & 4.21 & 2.91 & 2.41 & 2.88 & 0.41 & 2.60 & 0.32 \\
6 & 5.60 & 0.16 & 0.13 & 6.12 & 2.88 & 2.62 & 2.63 & 0.38 & 0.28 & 0.38 \\
\hline
\end{tabular}

6 Journal of Science and Technology, Vol. 29, No. 1, April, 2009 
environment and farm land making it unproductive for Agriculture. Furthermore, results showed that water from the area was toxic to human, plant and aquatic lives (Going by the values of $\mathrm{pH}$ range 4.9 and $55, \mathrm{Fe}, 0.28-0.43$ and other ions determined). Its consumption by inhabitants may likely cause water related diseases and death for animals. The adverse effects observed on plants were the unfavourable conditions created in the soil resulting in non-availability of nutrients and destruction of plants by toxic substances contained in the bitumen deposits. It can therefore be inferred that the presence of bitumen in this location has adversely affected soil fertility and cause great harm to farmers, most of whom have been displaced due to the barrenness of their farmlands.

The recommendations are as follows:

1. Planting of arable crops such as Palm tree, Cashew, Guava trees that can thrive well on acidic soil should be encouraged.

2. Usage of organic fertilizer to boost soil fertility should be encouraged to minimize problems arising from acidity since results show that soils in bitumen dominated areas are acidic.

3. In extreme cases, farmers should be relocated and resettled to areas where they can earn living by farming and adequate compensation be paid to them both by Government and prospecting companies.

4. Finally, appropriate legislation and policy must be put in place to preserve and protect the rights of the inhabitants of mineral deposits areas to prevent incessant clashes between the host communities, the prospecting companies and the Government

\section{REFERENCES}

Akinbile, C.O (2004). Public Health and Sanitation Implications of Hawked Water in Akure Metropolis, Journal of Applied Sciences 7(3): 43350- 4350.
Association of Official Analytical Chemists (AOAC). (1990). Official Methods of Analysis, $15^{\text {th }}$ Edition, Arlington, Virgina: 75-83, 249-255.

Eghagha, B. (2001). Beyond Resource control, The Guardian Newspaper, Friday September $14^{\text {th }}, 2001$.

Ekweozor, C.M and Unomah, G.F. (1989). "First discovery of Oil shale in the Benue Trough "Book of Abstract', 25 ${ }^{\text {th }}$ Annual conference of Nigerian Mineral and Geology Science, Ibadan pp 15-17.

Fayemi, A.A. (1975). The Effect of Soil Pollution on Germination, Growth and Nutrient Uptake of Corn, Journal of Environmental Quality, 4: 537-540.

Mimiko, F. (2000). The Political Economy of Natural Resources Exploitation in Nigeria, the Emergence of Bitumen Question, being paper presented at the International Summit on Bitumen, FUTA, November, pp 14-15.

Mink, E. (1991). Environmental Degradation on the People, Project Level guides for Environmental Sustainability, summarized from the World Bank Report.

Okeke, A.O and Okezie, D.W. (1987). Flaring of Associated Gas on Oil Industry, Impact on Growth Productivity and Yield of Selected Farm Crops, Izombe Floor Station Experience NNPC Workshop Port Harcourt, pp200205.

Ozumba, C.C. (1996). Harnessing the Potentials of the Nigerian Oil and Gas for Economic Development, Central Bank of Nigerian (CBN) Economy and Financial Review, 34 (4): 917-927. 